\title{
Investigation of the Effects of Splenectomy on Bone Healing (Experimental Study)
}

\author{
Splenektominin Kemik Iyileşmesine Etkilerinin Araştırılması (Deneysel Çalışma)
}

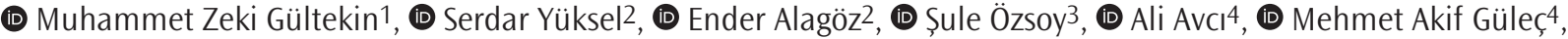 \\ (1) Zeynep Bayramoğlu5
}

1University of Health Sciences Turkey, Konya Training and Research Hospital, Clinic of Orthopedics and Traumatology, Konya, Turkey

2University of Health Sciences Turkey, İstanbul Bağcılar Training and Research Hospital, Clinic of Orthopedics and Traumatology, ístanbul, Turkey

3University of Health Sciences Turkey, İstanbul Bağcılar Training and Research Hospital, Clinic of Pathology, İstanbul, Turkey

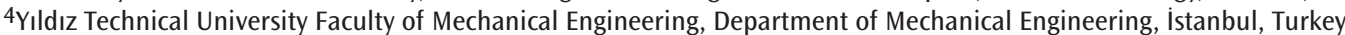

5 University of Health Sciences Turkey, Konya Training and Research Hospital, Clinic of Pathology, Konya, Turkey

\begin{abstract}
Introduction: This study is an experimental setup to examine the effects of splenectomy, applied to multi-trauma patients who are commonly seen in emergency traumatology practices and on fracture healing processes with respect to histopathological, biomechanical, and radiological aspects.

Methods: Further, 32 male Sprague Dawley rats (10 months old; average weight $394.5 \pm 28.3 \mathrm{~g}$ ) are included in the study. In a dark environment, rats are fed at $22{ }^{\circ} \mathrm{C}$ for 12 hours with standard rodent food ad libitum. They are divided into two groups: splenectomy (total splenectomy and long bone fracture healing) and control (only long bone fracture healing $\mathrm{n}=16$ ). Four months after surgery, rats are killed, and callus tissues in fractured femurs were examined histopathologically, radiologically, and biomechanically.

Results: In the radiological analysis of the femur materials in relation to the case and control groups, there was no substantial difference in the Goldberg classification score $(p>0.05)$. Similarly, no substantial difference was observed $(p>0.05)$ in histopathological examinations and biomechanical analysis conducted in femur samples.

Conclusion: When all of the results obtained in our study are evaluated together, it was concluded in the rats to which splenectomy is applied that this did not affect fracture healing histopathologically, biomechanically, and radiologically, despite the modification of immune modulators.
\end{abstract}

Keywords: Bone healing, splenectomy, immune

\section{öz}

Amaç: Bu çalıșma acil travmatoloji pratiğinde sıkça görülen bir durum olan multi travma hastalarında yapılan splenektominin kırık iyileşme sürecine olan etkilerini histopatolojik, biyomekanik ve radyolojik açıdan incelemek için olușturulmuş bir deneysel düzenektir.

Yöntemler: Çalıșmaya 32 erkek Sprague Dawley rat alındı (10

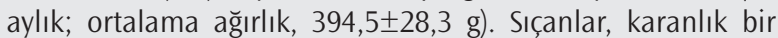
ortamda 12 saat boyunca $22{ }^{\circ} \mathrm{C}$ 'de standart kemirgen gıda ad libitumu ile beslendi. Splenektomi (toplam splenektomi ve uzun kemik kırık iyileșmesi) ve kontrol grubu (sadece uzun kemik kırık iyileșmesi $n=16$ ) olmak üzere iki gruba ayrıldı. Ameliyattan dört hafta sonra, sıçanlar sakrifiye edildi ve kırılan femurlarındaki kallus dokuları histopatolojik, radyolojik ve biyomekanik olarak incelendi.

Bulgular: Olgu ve kontrol grubunda gönderilen femur materyallerinin radyolojik incelemesinde yapılan Goldberg sınıflama skorlamasında anlamlı $(p>0,05)$ farklılık göstermemiștir. Yine gönderilen femur numunelerinde yapılan histopatolojik incelemeler ve biyomekaniksel analizlerde de anlamlı $(p>0,05)$ farklılık gösterilememiștir.

Sonuç: Çalıșmamızdan elde edilen tüm sonuçlar birlikte değerlendirildiğinde splenektomi yapılan sıçanlarda immün modülatörler üzerinde oluşturduğu modifikasyon değișikliğine rağmen kırık iyileșmesini histopatolojik, biyomekanik ve radyolojik olarak etkilemediği sonucuna varılmıștır.

Anahtar Kelimeler: Kemik iyileşmesi, splenektomi, bağışıklık

Address for Correspondence/Yazıșma Adresi: Zeynep Bayramoğlu MD, University of Health Sciences Turkey, Konya

Training and Research Hospital, Clinic of Pathology, Konya, Turkey

Phone: +90 5309387775 E-mail: drzeynepbayramoglu@hotmail.com ORCID ID: orcid.org/0000-0001-7075-8819

Received/Geliș Tarihi: 22.04.2020

Cite this article as/Atıf: Gültekin MZ, Yüksel S, Alagöz E, Özsoy Ş, Avcı A, Güleç MA, Bayramoğlu Z. Investigation of the Effects of Splenectomy on Bone Healing (Experimental Study). İstanbul Med J 2021; 22(1): 45-9.

(C) Copyright 2021 by the University of Health Sciences Turkey, Istanbul Training and Research Hospital/istanbul Medical Journal published by Galenos Publishing House.

(C) Telif Hakkı 2021 Sağıı Bilimleri Üniversitesi Istanbul Ĕgitim ve Araştırma Hastanesi/Istanbul Tıp Dergisi, Galenos Yayınevi tarafından basılmıștır. 


\section{Introduction}

In orthopedics and traumatology clinics, fracture healing is of great significance. Before discussing the factors influencing fracture healing, it would be beneficial to mention the fracture healing process. Fracture healing consists mainly of three stages: inflammation stage, repairing stage, and reshaping stage. Furthermore, major factors affecting this process are smoking cigarettes, soft tissue damage, infection, insufficient fracture stabilization, poor nutrition, age, and use of pharmacological agents (1-3). Fracture healing has two types: the first is primary fracture healing which occurs in the form of unification in fractures, and the second is secondary fracture healing which defines the unification of the fracture that is not determined.

There is an interaction at the cellular level between the immune system and the musculoskeletal system (4). Wound healing is positively affected by a decrease in CD8 cytotoxic T-lymphocyte count. Again, studies have shown that there is an increase in bone formation when there are no $\mathrm{B}$ lymphocytes following trauma (5).

The spleen is a core immune system organ where old and damaged erythrocytes and other circulating blood components and microorganisms are cleaned. Additionally, it is the second largest lymphoid organ due to its dense macrophage and dendritic cell content, including half of the body's lymphocytes. Since the spleen is the central organ of cellular and humoral immunity, immune function is its most important function (6). Lymphocytes are effector cells of the adaptive immune system, and their contribution to regenerative processes has been demonstrated (7). Some research has also shown a relationship between spleen function and bone metabolism at the cellular level. Despite this circumstance, the effect of the spleen on bone metabolism and remodeling has not yet been fully explained (8). However, bone resorption and formation are modulated by the interaction between $\mathrm{T}$ and $\mathrm{B}$ lymphocytes, dendritic cells, and cytokines on the immune system $(9,10)$.

The interaction between the immune system and bone metabolism has been discussed in numerous studies; however, to our knowledge, no study has considered the effects of the spleen and immune system on muscle and tendon metabolism. We also know that spleen-induced cytokines and cells play a significant role in tendon healing. Therefore, we assume that the spleen and immune system components may affect bone healing. Investigating this possibility, we designed a study model that examines the histopathological, radiological, and biomechanical mechanism of bone healing in patients with large bone fractures simultaneously in splenectomized rats. Our hypothesis before the study was to obtain better histopathological, immunohistochemical, and biomechanical results for the healing of femoral fractures in animals where splenectomy was performed. We figured this was because the rate of pro-inflammatory/anti-inflammatory cytokines in rats with splenectomy shifted in favor of anti-inflammatory cytokines and decreased inflammatory cells from the spleen.

\section{Methods}

According to the surgical procedures to be examined, 36 rats were randomly selected and divided into two groups of equal numbers. During the analysis, the rats were given unlimited tap water (ad libitum) and standard rodent feed. The animals were monitored at 22 degrees Celsius $\left({ }^{\circ} \mathrm{C}\right)$ in order to stay 12 hours in the light and 12 hours in the dark. Each group was operated by the same surgeon on the same day. Before surgery, a single dose of gentamicin $8 \mathrm{mg} / \mathrm{kg}$ was administered subcutaneously from the nape of the skin under the literature. The animals, with the requisite follow-up and preparations, were taken to the operating room. Moreover, the anesthetic drug dose was calculated by weighing each rat on an electronic scale. As an anesthetic, isoflurane was started at a $4 \%$ induction dose and continued at $2 \%$ for maintenance. The right knee areas of the rats were shaved and then stained with povidone-iodine (Batticon ${ }^{\circledR}$, ADEKA, Turkey). Anteromedially, the skin was passed through a $2 \mathrm{~cm}$ longitudinal incision. The joint capsule was opened from the medial patella. Patella was laterally overturned and knee flexed. The femur canal would be exposed, and the femur canal has been prepared using $1 \mathrm{~mm}$ Kirschner wire (TST, Istanbul) and electric drill (note: supplied by us) among the femur condoms. Then, the $0.8 \mathrm{~mm}$ Kirschner wire (TST, İstanbul) was placed in the prepared channel where the wire was compressed, pulled back 3-4 mm, and cut from the femoral condyle level. Furthermore, the residual wire in the channel was pushed back into the channel so that it did not come out of the condyle, the patella was reduced by extending the knee, the capsule was sutured with 3/0 vicryl (Atramat ${ }^{\circledR}$, Mexico) and skin with $2 / 0$ silk (Sterisilk ${ }^{\circledR}$, Turkey), and the wound is closed. Then, a $0.5 \mathrm{~cm}$ longitudinal incision was made at the midshaft level from the lateral of the thigh and was osteotomized from the femoral mid-soft (middle body) by applying even pressure through the costa scissors. In addition, the incision was closed following the skin and subcutaneous anatomy (Figure 1). Subsequently, a $3 \mathrm{~cm}$ midline incision was made in the abdomen, and the spleen was inspected and separated from its ligaments and removed from the abdomen. The veins in the spleen hilus and punch are dissected and ligated and cut, and the spleen is taken out of the abdomen. Following the clinical examination, the fracture was radiologically examined with a direct radiography on the surgery table with a portable X-ray device (Figure 2). All rats were sacrificed under general anesthesia by cervical dislocation in the $4^{\text {th }}$ week after all of these procedures. Further, 8 out of 16 rats in each group are sent for biomechanical examination after their bilateral femurs were removed, while the remaining 8 rats are sent for pathology after operated sides were amputated. All 16 rats in each group were X-rayed (Figure 2); this procedure was applied to all groups. All the radiographs obtained were scored by two separate orthopedists,

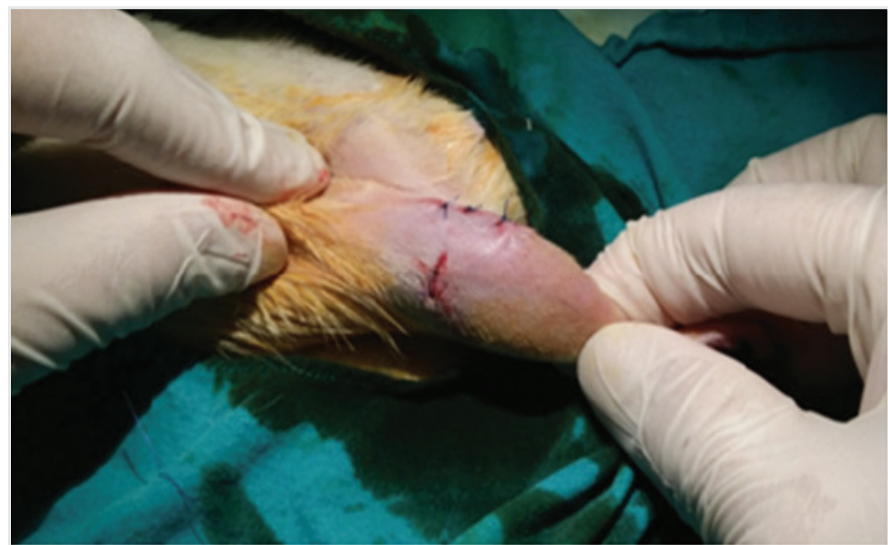

Figure 1. Creation of a femur fracture with a mini open incision 
independent of the experiment according to the Goldberg classification. Materials sent to pathology were made according to the histological healing scale published by Huo et al. (10) with respect to histological classification of healing (Figure 3). On the other hand, the materials sent to the biomechanics laboratory were also sent to Yıldız Technical University Faculty of Mechanical Engineering and Biomechanical Engineering with a wet sponge, frozen at $-20{ }^{\circ} \mathrm{C}$ and analyzed in terms of biomechanics. Then, the radiological and histological findings of the control and drug groups were evaluated using the Kruskal-Wallis test. As a result, the difference between the splenectomy group and the group that was not applied splenectomy was compared in terms of fracture healing. The study was approved by the Animal Experiments Ethics Committee of University of Health Sciences Turkey, İstanbul Bağcılar Training and Research Hospital, Turkey (approval number: HADYEK/2014-26, date: 23.07.2014).

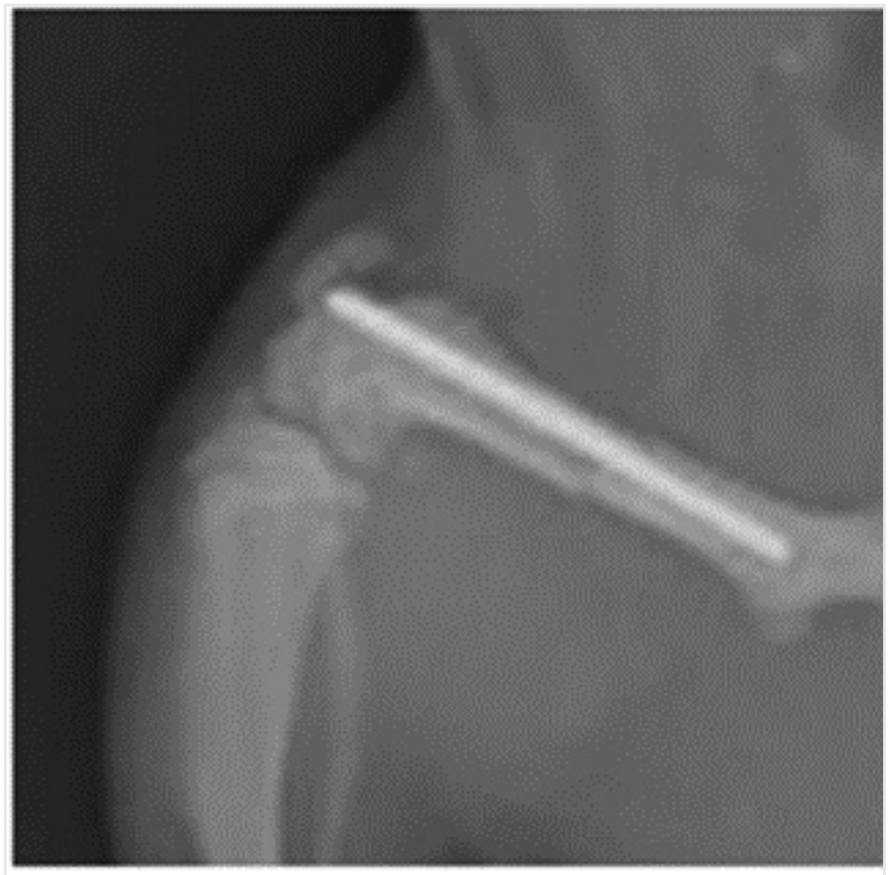

Figure 2. Early postoperative X-ray

\section{Statistical Analysis}

The SPSS 22.0 software was used in the analysis. Average, standard deviation, and median lowest and highest values were used in the descriptive statistics for all data collected. The distribution of variables is measured by the Kolmogorov-Smirnov test. In the analysis of quantitative data, the Mann-Whitney U test and Independent Samples t-test were used. The Paired Samples t-test was used for the study of repeated measurements. Moreover, the Kappa fit test was used for fit analysis.

\section{Results}

In the case and control group, the Goldberg classification score did not vary significantly $(p>0.05)$. Also, the histopathological score did not differ significantly in the case and control groups ( $p>0.05$ ) (Table 1).

The Goldberg classification assessment of the first and second orthopedists was substantially in conformity $(p=0.000 / \mathrm{Kappa}=0.619)$ (Table 2).

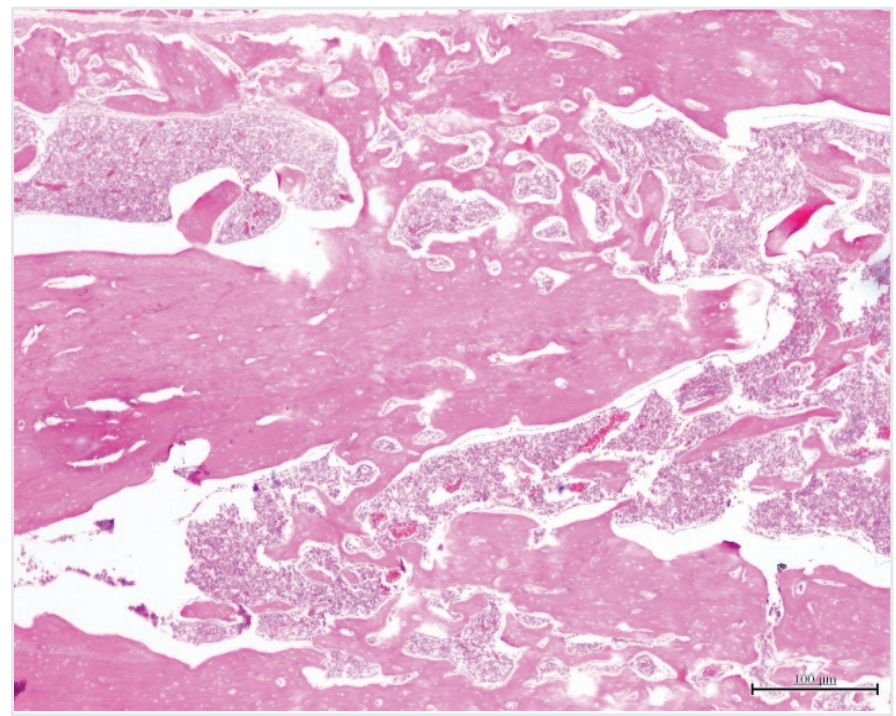

Figure 3. Mature bone (hematoxylin-eosin staining x40 magnification)

Table 1. Analysis of radiological and histopathological results

\begin{tabular}{|l|l|l|l|l|}
\hline & \multicolumn{2}{|l|}{ Control group } & Case group & p \\
\cline { 2 - 5 } & Mean \pm SD & Med (min-max) & Mean \pm SD & Med (min-max) \\
\hline Goldberg classification & $2.8 \pm 0.4$ & $3.02 .0-3.0$ & $2.6 \pm 0.6$ & $2.91 .0-3.0$ \\
\hline Histopathologic score & $6.9 \pm 0.9$ & $6.55 .5-8.0$ & $6.9 \pm 1.2$ & $7.05 .0-8.3$ \\
\hline
\end{tabular}

Independent sample t-test, Mann-Whitney U test, SD: standard deviation, min: minimum, max: maximum

Table 2. Compatibility analysis table among orthopedists

\begin{tabular}{|c|c|c|c|c|c|c|c|c|}
\hline & & \multicolumn{4}{|c|}{ Orthopedic surgeon 2 Goldberg scores } & \multirow{2}{*}{$\%$ Conformity } & \multirow{2}{*}{ Kappa } & \multirow{2}{*}{$\mathbf{p}$} \\
\hline & & 1 & 2 & 2.5 & 3 & & & \\
\hline \multirow{3}{*}{$\begin{array}{l}\text { Orthopedic surgeon } 1 \\
\text { Goldberg scores }\end{array}$} & 1 & 1 & 0 & 0 & 0 & \multirow{3}{*}{$93 \%$} & \multirow{3}{*}{0.619} & \multirow{3}{*}{0.000} \\
\hline & 2.5 & 0 & 1 & 0 & 2 & & & \\
\hline & 3 & 0 & 0 & 1 & 19 & & & \\
\hline
\end{tabular}


In the case and control groups, the robust biomechanical measurements did not differ significantly ( $p>0.05$ ). In addition, in the case and control groups, the broken side biomechanical measurements did not vary significantly $(p>0.05)$. However, in the control group, the biomechanical measurement of the broken side was significantly lower $(p=0.001)$ from the strong side. Also, in the case group, the broken side biomechanical measurement was significantly lower $(p=0.001)$ from the strong side (Table 3).

\section{Discussion}

In this experimental study, we examined and compared the effect of splenectomy on the healing of femoral fractures in rats that were treated with splenectomy and in rats not treated with splenectomy. Despite having positive and negative effects in the literature, we could not show any effect differently. In other words, the healing process in rats with and without splenectomy was biomechanically, radiologically, and histopathologically indifferent. In this regard, there are studies with different study designs in the literature, and we compared some of them with the results of our study. Zhang et al. (11) showed that the antiinflammatory effect of splenectomy reduces the amount of cerebral infarction. However, the anti-inflammatory mechanism of action that emerged after splenectomy could not be explained in the same study. These researchers showed that the number of CD4+ and CD3+ T lymphocytes decreased after splenectomy (11). However, in a 2011 study by Milićević et al. (12), it was shown that the number of B lymphocytes increased 3 months after splenectomy, but there was no change in the number of T lymphocytes, natural killer cells, macrophages, neutrophils, and monocytes. Also, in their studies, Arakawa et al. (13) demonstrated the anti-inflammatory effect of splenectomy on the portal system.

In a recent study, immune function changes after splenectomy had an effect on fracture healing. For this reason, it was said that the spleen should be preserved in order to heal the fracture (14). In the same study, low levels of IL-1 $\beta$ and TNF- $\alpha$, which are pro-inflammatory cytokines, were detected. Furthermore, they also showed that splenectomy negatively reduced RANKL expression and affected collagen synthesis and fibroblast differentiation and that these changes cause a delay in bone healing. However, according to our study, their weak points were that they did not biomechanically investigate bone healing. In their study in the splenectomized rats, Sun et al. (15) and Toben et al. (16) showed that splenectomy increased bone formation.

Sun et al. (15) reported that T lymphocytes had a negative effect on bone healing and had negative effects at the early stage of fracture healing. This process was clarified by increased interaction between T lymphocytes and RANK-RANKL and increased osteoclastogenesis. They also emphasized that the reduction of pro-inflammatory cytokines released from activated $T$ lymphocytes, monocytes, and macrophages is effective in these processes. In parallel with this study, lower levels of IL-1 TN, TNF- $\alpha$, and IFN- $\gamma$ were observed, as well as higher levels of IL-10 and IL-4.

Nakamichi et al. (17) showed that TNF- $\alpha$ levels decreased after splenectomy and that this resulted in a decrease in the number of osteoclasts and that, as a consequence of all these inflammatory changes, splenectomy had a positive impact on bone healing. Lehmann et al. (18) showed in their study that the decrease in TNF- $\alpha$ signal reduced fracture healing and that the positive or negative effect of TNF- $\alpha$ was dose-dependent. Toben et al. (16) emphasized that IFN- $\gamma$ levels were low in lymphatic rats and reduced macrophage activation and tissue destruction (16). Another study found that IL-10 levels increased in immune system deficiency, inhibiting the secretion of pro-inflammatory cytokines, which had a positive effect on bone healing (19). IL-2 is considered to be an important T-cell growth factor (20). One study found that rats with immune deficiencies (excluding IL-2 deficiency) increased bone healing. In the same study, the level of IL-2 in the splenectomy group was found to be high as other other anti-inflammatory cytokines (21). In a recent study, immune function changes after splenectomy affect fracture healing. For this reason, it was said that the spleen should be preserved in order to heal the fracture.

\section{Conclusion}

Although there is no consensus in all the studies being conducted, the works that are realized have deficient aspects. The most important indicator of the healing process in orthopedic practice is how much the bone can be restored in terms of biomechanics. Other healing markers are changes in microlevel, and the most noticeable parameter of the clinical outcome is the resistance level of the callus. In our study, biomechanical, histopathological, and radiological effects of splenectomy on fracture healing were not shown. However, the shortcomings of our study are that the level of immunofluorescence and inflammatory mediators cannot be measured and that the amount of callus is not quantitatively measured by micro-CT. Therefore, we recommend that the extended study plans be made by completing the limitations of our study.

\section{Acknowledgment}

We would like to thank University of Health Sciences Turkey, İstanbul Bağcılar Training and Research Hospital Experimental Research and Skill Development Center (BADABEM) for their contributions and support.

Table 3. Biomechanical values of the groups' solid and broken sides (Newton)

\begin{tabular}{|c|c|c|c|c|c|c|c|c|}
\hline & & Control grou & & & Case group & & & \\
\hline & & Mean \pm SD & & Med (min-max) & Mean \pm SD & & Med (min-max) & P \\
\hline Ripmechanics & Solid side & $178.2 \pm 23.2$ & 177 & $151-220$ & $199.8 \pm 33.5$ & 202 & $154-244$ & 0.186 \\
\hline Difference $p$ & & 0.001 & & & 0.000 & & & \\
\hline
\end{tabular}




\section{Ethics}

Ethics Committee Approval: The study was approved by the Animal Experiments Ethics Committee of University of Health Sciences Turkey İstanbul Bağcılar Training and Research Hospital, Turkey (approval number: HADYEK/2014-26, date: 23.07.2014).

Informed Consent: Patient approval has not been obtained as it is performed on animals.

Peer-review: Externally and internally peer-reviewed.

Authorship Contributions: Surgical and Medical Practices - M.Z.G., S.Y., E.A., Ș.Ö., M.A.G.; Concept - M.Z.G., S.Y., E.A., Ș.Ö., M.A.G.; Design - M.Z.G., S.Y., E.A., S..̈., M.A.G.; Data Collection or Processing - M.Z.G., S.Y., A.A., M.A.G., Z.B.; Analysis or Interpretation - M.Z.G., A.A., Z.B.; Literature Search - M.Z.G., Z.B.; Writing - M.Z.G., Z.B.

Conflict of Interest: No conflict of interest was declared by the authors.

Financial Disclosure: As they assisted us in biomechanical laboratory analysis, we got support from Dr. Onur Küçükyıldırım and Mr. Ali Avcı from Yıldız Technical University Machine Engineering Department and Advanced Material Research Group.

\section{References}

1. Pountos I, Georgouli T, Blokhuis TJ, Pape HC, Giannoudis PV. Pharmacological agents and impairment of fracture healing: what is the evidence? Injury 2008; 39: 384-94.

2. Castellá FB, Garcia FB, Berry EM, Perelló EB, Sánchez-Alepuz E, Gabarda R. Nonunion of the humeral shaft: long lateral butterfly fracture-a nonunion predictive pattern? Clin Orthop Relat Res 2004; 227-30.

3. Demirtas A, Azboy I, Bulut M, Ucar BY, Alabalik U, Necmioglu NS. Investigation of the effects of Enoxaparin, Fondaparinux and Rivaroxaban used in thromboembolism prophylaxis on fracture healing in rats. Eur Rev Med Pharmacol Sci 2013; 17: 1850-6.

4. Takayanagi H. Osteoimmunology: shared mechanisms and crosstalk between the immune and bone systems. Nat Rev Immunol 2007; 7: 292-304.

5. Marusic A, Grcevic D, Katavic V, Kovacic N, Lukic IK, Kalajzic I, et al. Role of B lymphocytes in new bone formation. Lab Invest 2000; 80: 1761-74.

6. Tarantino G, Savastano S, Capone D, Colao A. Spleen: A new role for an old player? World J Gastroenterol 2011; 17: 3776-84.

7. Park JE, Barbul A. Understanding the role of immune regulation in wound healing. Am J Surg 2004; 187: 11S-6S.

8. Tyagi AM, Srivastava K, Sharan K, Yadav D, Maurya R, Singh D. Daidzein prevents the increase in $C D 4+C D 28$ null $T$ cells and B lymphopoesis in ovariec- tomized mice: a key mechanism for anti-osteoclastogenic effect. PLOS ONE 2011; 6: e21216.

9. Cenci S, Toraldo G, Weitzmann MN, Roggia C, Gao Y, Qian WP, et al. Estrogen deficiency induces bone loss by increasing $T$ cell proliferation and lifespan through IFN-gamma-induced class II transactivator. Proc Natl Acad Sci U S A 2003; 100: 10405-10

10. Huo MH, Troiano NW, Pelker RR, Gundberg CM, Friedlaender GE. The influence of ibuprofen on fracture repair: biomechanical, biochemical, histologic and histomorphometric parameters in rats. J Orthop Res 1991; 9: 383-90.

11. Zhang BJ, Men XJ, Lu ZQ Li HY, Qui W, Hu XQ. Splenectomy protects experimental rats from cerebral damage after stroke due to anti-inflammatory effects. Chin Med J (Engl) 2013; 126: 2354-60.

12. Milićević NM, Luettig B, Trautwein C, Wüstefeld T, Mähler M, Jecker P, et al. Splenectomy of rats selectively reduces lymphocyte function-associated antigen 1 and intercellular adhesion molecule 1 expression on B-cell subsets in blood and lymph nodes. Blood 2001; 98: 3035-41.

13. Arakawa Y, Shimada M, Uchiyama H, Ikegami T, Yoshizumi T, Imura S, et al. Beneficial effects of splenectomy on massive hepatectomy model in rats. Hepatol Res 2009; 39: 391-7.

14. Xiao W, Hu Z, Li T, Li J. Bone fracture healing is delayed in splenectomic rats. Life Sci 2017; 173: 55-61.

15. Sun D, Zheng X, Chen Y, Jia C, Xu S, Lin C, et al. Enhancement of osteogenesis post-splenectomy does not attenuate bone loss in ovariectomized rats. J Orthop Res 2015; 33: 1356-63.

16. Toben D, Schroeder I, El Khassawna E, Mehta M, Hoffmann JE, Frisch JT, et al. Fracture healing is accelerated in the absence of the adaptive immune system. J Bone Miner Res 2011; 26: 113-24.

17. Nakamichi Y, Mizoguchi T, Arai A, Kobayashi Y, Sato M, Penninger JM, et al. Spleen serves as a reservoir of osteoclast precursors through vitamin D-induced IL-34 expression in osteopetrotic op/op mice. Proc Natl Acad Sci U SA 2012; 109: 10006-11.

18. Lehmann W, Edgar CM, Wang K, Cho TJ, Barnes GL, Kakar S, et al. Tumor necrosis factor alpha (TNF- alpha) coordinately regulates the expression of specific matrix metalloproteinases (MMPS) and angiogenic factors during fracture healing. Bone 2005; 36: 300-10.

19. Grütz G. New insights into the molecular mechanism of interleukin-10mediated immunosuppression. J Leukoc Biol 2005; 77: 3-15.

20. Malek TR. The biology of interleukin-2. Annu Rev Immunol 2008; 26: 453-79.

21. Schneider GB, Relfson M. Effects of interleukin-2 on bone resorption and natural immunity in osteopetrotic (ia) rats. Lymphokine Cytokine Res 1994; 13: 335-41. 